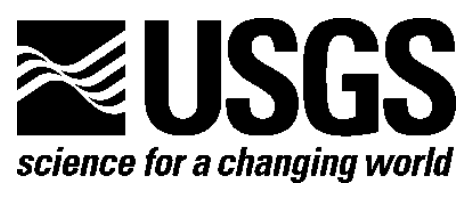

\title{
Surficial Geologic Map of the Dillingham Quadrangle, Southwestern Alaska
}

By Frederic H. Wilson

Pamphlet to accompany

Scientific Investigations Map 3388

U.S. Department of Interior

U.S. Geological Survey 


\section{U.S. Department of the Interior \\ RYAN K. ZINKE, Secretary}

\section{U.S. Geological Survey James F. Reilly II, Director}

U.S. Geological Survey, Reston, Virginia: 2018

For more information on the USGS-the Federal source for science about the Earth, its natural and living resources, natural hazards, and the environment-visit https://www.usgs.gov/ or call 1-888-ASK-USGS (1-888-275-8747).

For an overview of USGS information products, including maps, imagery, and publications, visit https://store.usgs.gov/.

Any use of trade, firm, or product names is for descriptive purposes only and does not imply endorsement by the U.S. Government.

Although this information product, for the most part, is in the public domain, it also may contain copyrighted materials as noted in the text. Permission to reproduce copyrighted items must be secured from the copyright owner

Suggested citation:

Wilson, F.H., 2018, Surficial geologic map of the Dillingham quadrangle, southwestern Alaska: U.S. Geological Survey Scientific Investigations Map 3388, 15 p., scale 1:250,000, https://doi.org/10.3133/sim3388. 


\section{Contents}

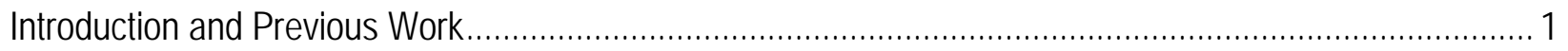

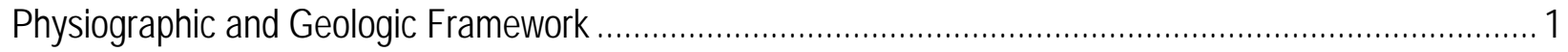

Discussion-Quaternary Geology and Mapping of Surficial Deposits ................................................... 4

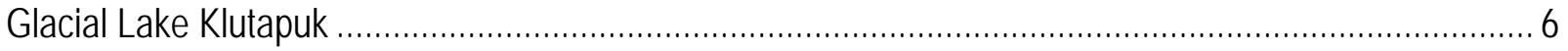

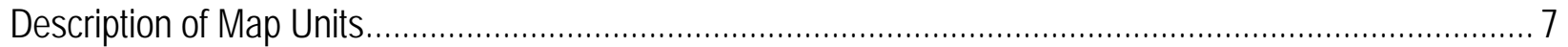

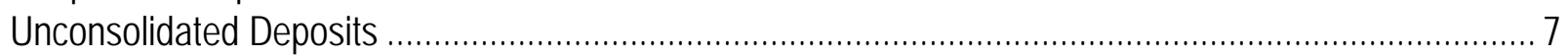

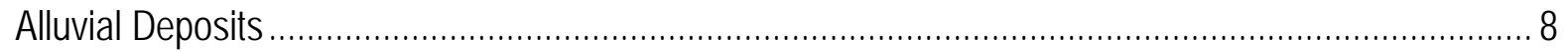

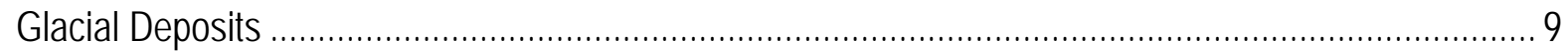

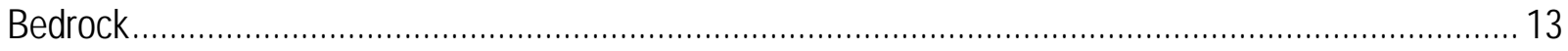

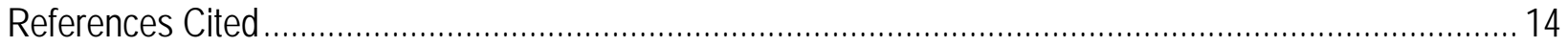

\section{Figures}

1. Physiographic provinces of southwestern Alaska ……................................................... 3

2. Map showing geographic landmarks and moraine limits for the glacial advances discussed in the text

\section{Tables}

1. Correlation of glacial advances in the Dillingham quadrangle on the basis of morphology and spatial relations. 


\section{Surficial Geologic Map of the Dillingham Quadrangle, Southwestern Alaska}

By Frederic H. Wilson

\section{Introduction and Previous Work}

This map and accompanying digital files are the result of the interpretation of black and white aerial photographs from the 1950s as well as more modern imagery. The photographs, printed at a nominal scale of 1:40,000, were flown by the U.S. military and are the imagery used to produce the published Dillingham topographic series 1:250,000- and 1:63,360-scale maps. Modern satellite imagery, accessed through Google Earth, was used to provide an overview and context. The map area, part of Alaska that was largely not glaciated during the late Wisconsin glaciation (see Karlstrom, 1964; Coulter and others, 1965; or Péwé, 1975), has a long history reflecting local and more distant glaciations. Late Wisconsin glacial deposits have limited extent in the eastern part of the quadrangle, but are quite extensive in the western part of the quadrangle.

An unpublished photogeologic map of the Dillingham quadrangle compiled in the 1950s by J.N. Platt, Jr. and E.H. Muller ${ }^{1}$ was useful in the construction of this map. The Platt and Muller 1950s-era aerial photographic interpretation map was the starting point for my mapping of the surficial geology; their unpublished data were plotted on an older U.S. Geological Survey (USGS) Reconnaissance Topographic Series topographic map base. In addition to transferring their data to the modern, higher quality Topographic Series base map, I re-examined all of the aerial photographs. Limited new field mapping in the area was conducted as part of a bedrock mapping project in the northeastern part of the quadrangle (Wilson and others, 2003); however, extensive aerial photographic interpretation represents the bulk of the mapping effort. In a number of areas, I reinterpreted the features mapped by Platt and Muller and revised the linework as needed. A major difference between the maps is my reassignment of some glacial deposits to different glacial processes or events.

\section{Physiographic and Geologic Framework}

Wahrhaftig (1965) divided Alaska into a hierarchical system of physiographic divisions, provinces, and sections. Alaska was divided into five divisions, two of which, the Pacific Mountains division in the east and the Intermontane Plateaus division in the west, are shown on figure 1. The Dillingham quadrangle lies entirely within the Intermontane Plateau division and

\footnotetext{
${ }^{1}$ Hard copy of this unpublished compilation can be examined at the USGS Alaska Technical Data Unit in Anchorage, Alaska. The compilation is not dated, but our best estimate is that it was produced in the late 1950s.
} 
encompasses parts of two provinces; these are the Ahklun Mountains province in the west and the Western Alaska province, which is further subdivided into a number of sections, as shown on figure 1. West of the Aleutian Range section of the Pacific Mountains division, primarily in the region of Iliamna Lake, glacial landforms primarily consist of end or recessional moraines. Glaciolacustrine deposits dominate the landscape in the Nushagak-Big River Hills and Nushagak-Bristol Bay Lowland sections of the Western Alaska province. The Dillingham quadrangle encompasses parts of the Western Alaska and Ahklun Mountains physiographic provinces (fig. 1), as defined by Wahrhaftig (1965). The majority of the quadrangle lies within the Western Alaska province, much of that in the Nushagak-Bristol Bay Lowland section. The western part of the quadrangle lies within the Ahklun Mountains province and contains the majority of the exposed bedrock in the quadrangle. Other bedrock exposures are in the northeast corner of the quadrangle. The bulk of the map area consists of heavily vegetated, but treeless, rolling hills that may be covered by local accumulations of eolian deposits, including loess. Péwé (1975) shows the area as reflecting Wisconsin and Illinoian glaciation. In the western part of the quadrangle, within the Ahklun Mountains province, the mountains and finger lakes are strongly affected by Pleistocene and Holocene glaciation (Briner and Kaufman, 2000). In particular, the finger lakes of Wood-Tikchik State Park are well-developed landlocked fjords (fig. 2). Extensive glacial deposits provide abundant evidence of glaciers that advanced into the quadrangle from the east and west, and probably coalesced in the quadrangle during the early Pleistocene. In the lowland part of the quadrangle, a number of isolated knobs were found to be thinly covered granitic plutons of latest Cretaceous or Paleocene age.

The Mulchatna and Nushagak Rivers traverse the quadrangle from northeast to southwest. East of these rivers is the type area of the Kvichak advance of the Brooks Lake glaciation (Detterman, 1986), which reflects the maximum extent of glaciation during the late Wisconsin (see table 1). The Brooks Lake glaciation is divided into four advances; only the Kvichak advance reached the Dillingham quadrangle from the Aleutian Range. West of the rivers, glacial deposits of the Okstukuk ${ }^{2}$ advance are thought to represent the late Wisconsin glacial maximum as derived from the Ahklun Mountains (see table 1 for age correlation). This advance may have been synchronous with the Kvichak advance; controls on the age are lacking, but morphologically the deposits are similar. Late glacial advances or re-advances from the Ahklun Mountains are mapped as the Aleknagik advance, which has not been subdivided as has the Brooks Lake glaciation. Lea (1989) correlated the Aleknagik maximum extent with the Iliamna advance of the Brooks Lake glaciation.

Arcuate end and recessional moraines formed dams that produced a large number of ephemeral lakes. Many lakes in the Lake Clark and Iliamna quadrangles to the east and northeast of the Dillingham quadrangle, including the largest of all, Iliamna Lake (fig. 1), are remnants of these earlier lakes. Lacustrine deposits west of Iliamna Lake and extending into the southeast Dillingham quadrangle, as well as deposits along many of the rivers of the region, provide evidence that these lakes were more extensive in the past. It is similarly true that the lakes on the west side of the quadrangle were more extensive in the past. Mertie (1938, p. 67) reports that a "system of terraces" along the slopes above the lakes indicates higher lake levels. The unconsolidated deposits of the central part of the quadrangle are largely of early Wisconsin and older age and reflect a much-subdued topography. Locally, these older glacial deposits appear to display evidence of being over-run by water. The draining of ancestral Lake Klutapuk in the

${ }^{2}$ Platt and Muller (late 1950s) coined the names Okstukuk and Aleknagik for glacial advances. 
Taylor Mountains quadrangle to the north (Wilson, 2015) may have been the source of this flooding. Evidence of higher relative sea level is apparent in the southwestern part of the quadrangle, where estuarine deposits are present along the Nushagak River.

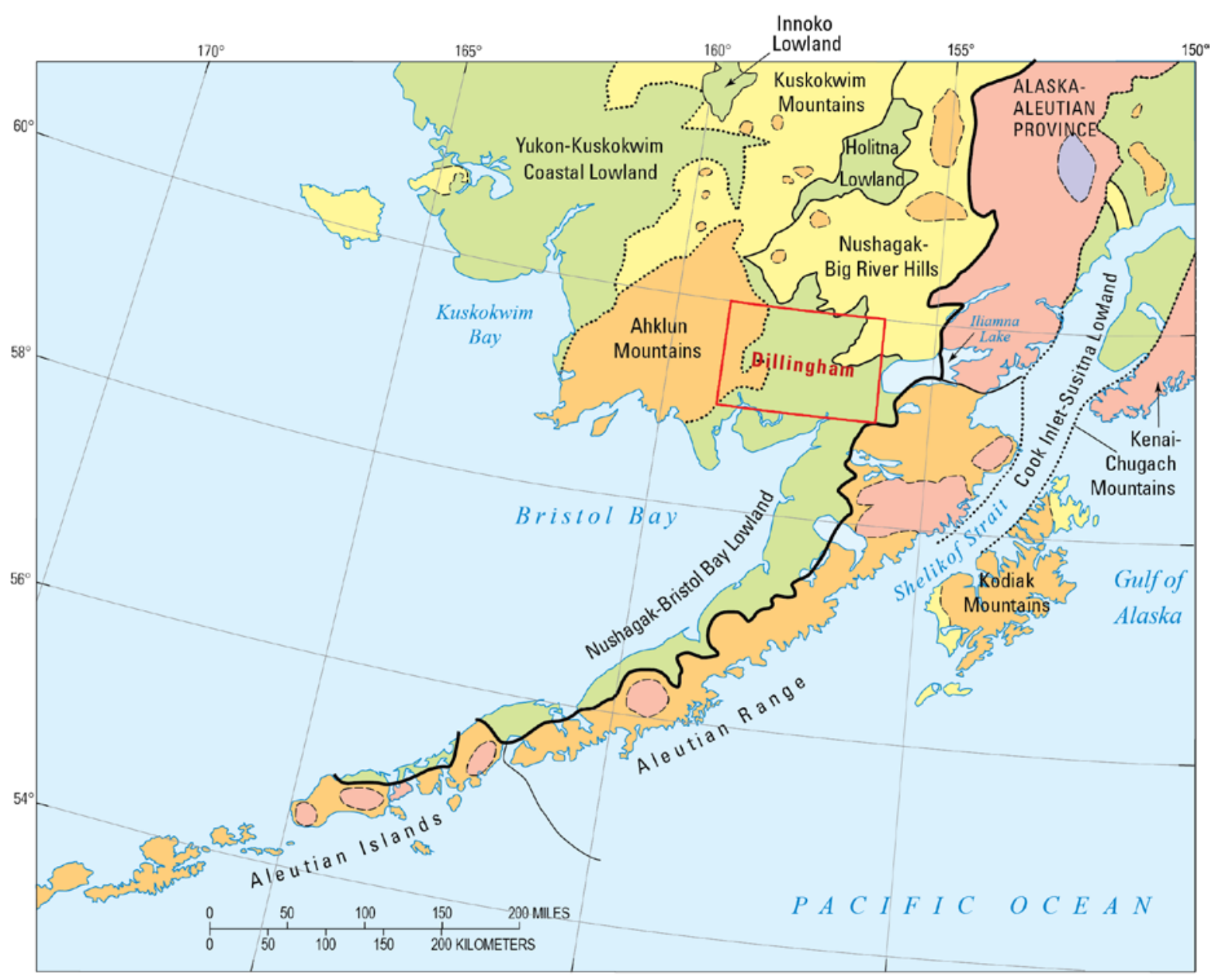

EXPLANATION
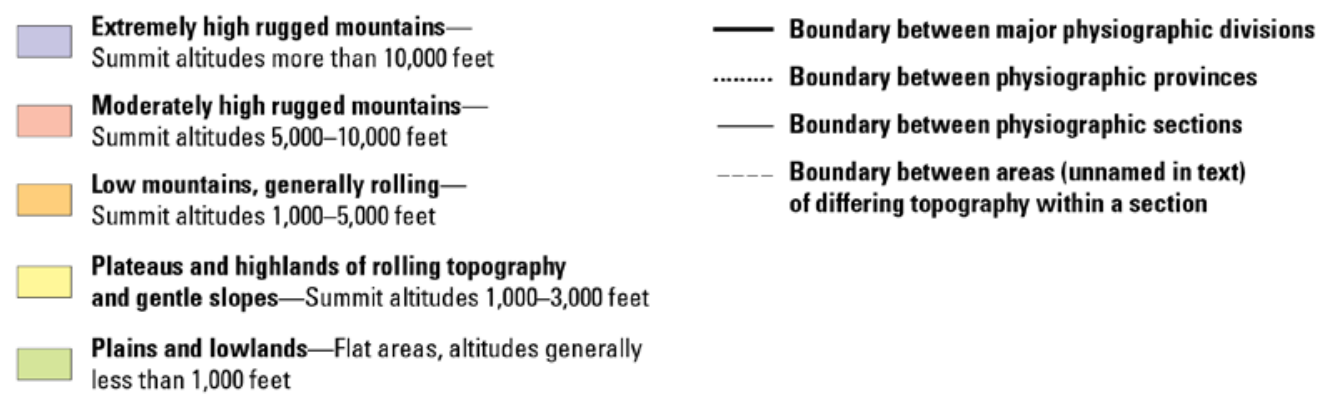

Figure 1. Physiographic provinces of southwestern Alaska after Wahrhaftig (1965). Dillingham quadrangle outlined in red. The Ahklun Mountains province covers the western part of the quadrangle. Glaciers from the Alaska Range (Southern Part) division and the Ahklun Mountains province advanced into the map area during the Pleistocene. The Pacific Mountains division of Wahrhafting (1965) is east of the heavy black line; the Intermontane Plateaus division is west of the line. The Western Alaska province (not labeled) includes the Nushagak-Bristol Bay Lowland, Nushagak-Big River Hills, Holitna Lowland, and Kuskokwim Mountains sections. 
Table 1. Correlation of glacial advances in the Dillingham quadrangle on the basis of morphology and spatial relations. Lea (1989) suggested that the Aleknagik and Okstukuk advances reflected the late Wisconsin glacial maximum on the basis of their fresh morphology.

\begin{tabular}{|c|c|c|c|}
\hline Age & $\begin{array}{l}\text { Ahklun Mountains (J.N. Platt and } \\
\text { E.H. Muller, USGS, unpub. data) }\end{array}$ & \multicolumn{2}{|c|}{ Alaska Peninsula (Detterman, 1986) } \\
\hline Holocene & Unnamed & \multicolumn{2}{|c|}{ Neoglaciation } \\
\hline \multirow[t]{2}{*}{ Late Wisconsin } & Aleknagik glaciation & \multirow[t]{2}{*}{ Brooks Lake glaciation } & $\begin{array}{l}\text { Iliuk advance } \\
\text { Newhalen advance } \\
\text { Iliamna advance }\end{array}$ \\
\hline & Okstukuk glaciation & & Kvichak advance \\
\hline Early Wisconsin & Iowithla glaciation & \multicolumn{2}{|c|}{ Mak Hill glaciation } \\
\hline Pre-Wisconsin & Unnamed glaciation & \multicolumn{2}{|c|}{ Johnston Hill(?) glaciation and "oldest drift" } \\
\hline
\end{tabular}

Bedrock is sparsely exposed within the quadrangle and has only been mapped at a reconnaissance scale (Hoare and Coonrad, 1978; Wilson and others, 2006; Wilson and others, 2017), except for the northeast corner of the quadrangle (Wilson and others, 2003). The so-called Mulchatna Fault may enter the northeastern part of the quadrangle trending northeast-southwest (Beikman, 1980; Mohadjer and others, 2006); however, while it is clearly a topographic lineament north of the quadrangle, there is little geologic or geophysical evidence to support its continuation into the Dillingham quadrangle.

Bedrock in the northeastern margin of the quadrangle consists largely of latest Cretaceous and earliest Paleocene granitic plutons, and minor sedimentary rocks of apparent late Jurassic age (Wilson and others, 2003). Paleozoic and Mesozoic rock units, including mélange, are found in the northwestern part of the quadrangle (Wilson and others, 2006). The western part of the map area and the majority-exposed bedrock is composed of Jurassic to Cretaceous-age volcaniclastic sedimentary and volcanic rocks that are, in turn, intruded by latest Cretaceous to early Tertiary granitic plutons (Hoare and Coonrad, 1978; Wilson and others, 2006). A few of the prominent hills or knobs present in the vast plain of unconsolidated deposits in the quadrangle were found to be thinly covered bedrock exposures of additional granitic plutons. Available aeromagnetic survey data show the presence of a number of highly magnetic areas in the central part of the quadrangle (Saltus and Simmons, 1997); however, other than one granitic pluton exposed on a knob southeast of Ekwok, no bedrock is exposed over this area of high magnetic intensity. A few kilometers east of Kemuk Mountain, a large mafic and ultramafic complex is buried under 25 to 40 meters of unconsolidated, largely glacial deposits (Berg and Cobb, 1967, p. 11). Where granitic plutonic rocks are well-exposed in the northeastern part of the quadrangle, no magnetic anomalies are shown.

\section{Discussion-Quaternary Geology and Mapping of Surficial Deposits}

The Quaternary geologic units shown on this map are the products of multiple glacial events, as well as periglacial processes in the less recently glaciated areas. The map area also lies within the zones of discontinuous and sporadic permafrost (Ferrians, 1965; Jorgenson and others, 2008). A small area of solifluction deposits occurs along the eastern border of the map area, derived from local upslope bedrock sources in the western part of the adjacent Iliamna quadrangle. Alluvial and colluvial deposits in the quadrangle are most commonly derived from reworking of glacial deposits and, to a lesser extent, eroding bedrock. Surficial deposits in much of the map area are either direct deposits of glaciers or their outwash. Deposits of Holocene, late Wisconsin, early Wisconsin, and pre-Wisconsin age are recognized in the map area, and landforms suggest that earlier glacial episodes had a significant impact. Morphologically 


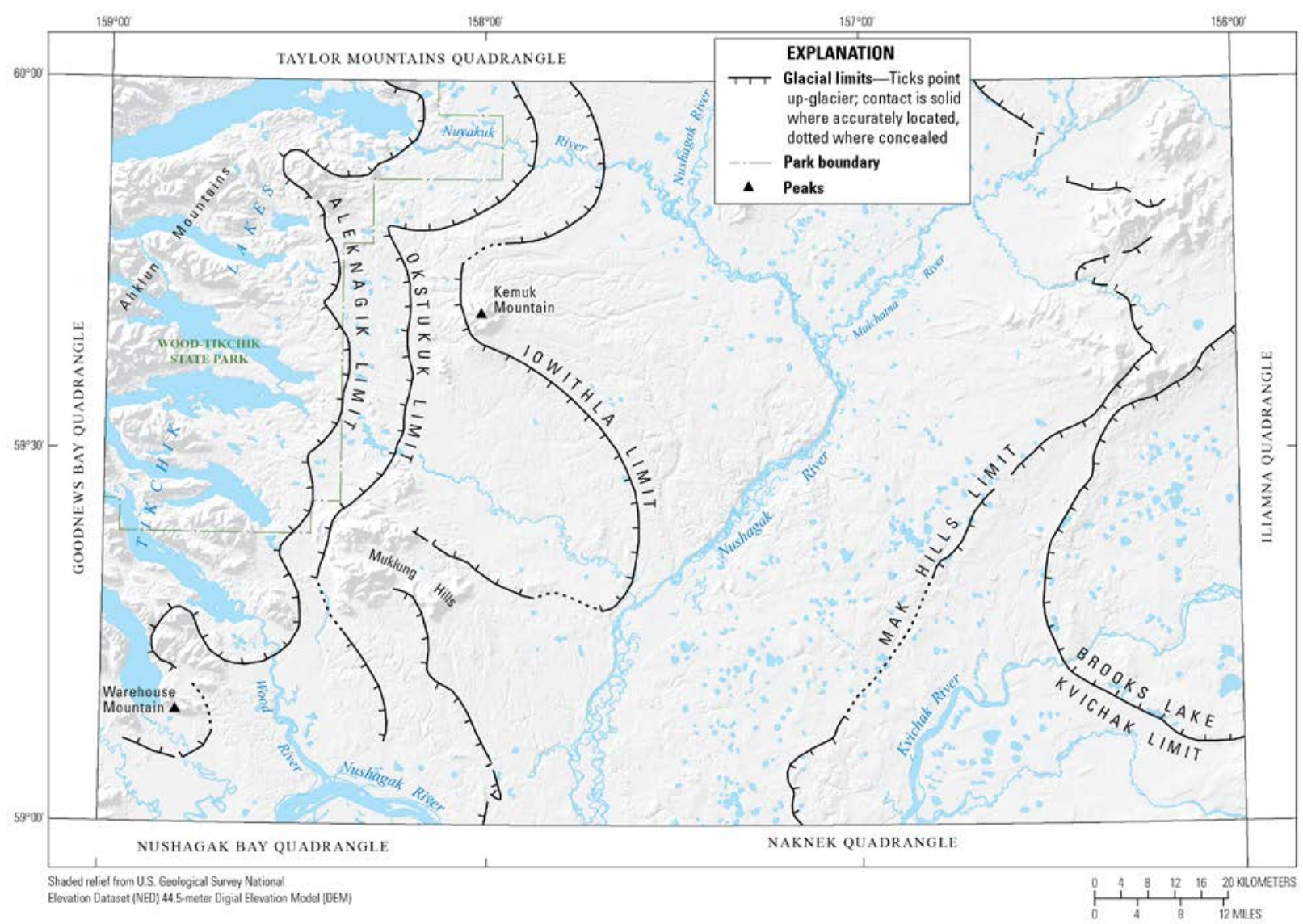

Figure 2. Map showing geographic landmarks and moraine limits for the glacial advances discussed in the text.

indistinct deposits throughout the central area of the quadrangle are interpreted to be primarily ground moraine deposits of early glacial advances derived from both east and west.

Mertie (1938) was the first to report and discuss the glacial deposits in this part of Alaska, although he did not map them. On the Alaska Peninsula, Abrahamson (1949) named the deposits of the Mak Hill glaciation and Muller (1953) named the deposits of the Brooks Lake glaciation; these names are extended into the eastern part of the Dillingham quadrangle here. Muller (1953) briefly discussed the glacial deposits in the western Nushagak River basin. The Aleknagik, Okstukuk, and Iowithla glaciations were named by J.N. Platt, Jr. and E.H. Muller in their unpublished USGS map manuscript for the Dillingham quadrangle, and by J.N. Platt, Jr. in the Taylor Mountains quadrangle (circa 1957). Platt and Muller correlated the Aleknagik glaciation with the Brooks Lake glaciation, and the Okstukuk glaciation with the Mak Hill glaciation, and interpreted the Iowithla glaciation as a yet older event. Alternately, Lea (1989) correlated the Aleknagik glaciation with the Iliamna advance of the Brooks Lake glaciation, and the Okstukuk glaciation with the Kvichak advance of the Brooks Lake; this is the correlation shown here in table 1.

Deposits of the youngest glacial advances are located in cirques, and include moraines that have limited extent. Earlier deposits of the late Wisconsin Brooks Lake glaciation (Detterman, 1986) are well-represented on the west side of the Alaska and Aleutian Ranges (hereafter the Alaska-Aleutian Range), which form the topographic backbone of southwestern Alaska. The Kvichak advance type area, the oldest of these deposits, is found in the southeast corner of the Dillingham quadrangle. The western periphery of the map area is conceptually the glacial mirror image of the western Alaska-Aleutian Range. During the late Wisconsin, glaciers 
assigned to the Aleknagik and older Okstukuk advances flowed eastward from the Ahklun Mountains (also locally called the Wood River Mountains). These glaciers carved deep, fjordlike glacial lakes and left extensive morainal and outwash deposits. These advances are correlated with the Brooks Lake glaciation of the Alaska-Aleutian Range (table 1), the timing of which is supported by Manley and others (2001), who placed radiocarbon and morphological constraints on the age of glacial advances in the Ahklun Mountains. In part, these glacial deposits rim and form dams that enclose spectacular land-locked fjords, containing the finger lakes of the Togiak-Tikchik and Wood River region.

Down-glacier from the Brooks Lake and Okstukuk deposits are well-preserved end moraines of the Mak Hill and Iowithla glacial advances in the eastern and western parts of the map area, respectively. Outwash deposits derived from the Mak Hill advance appear to have limited extent except in the northeastern part of the map area; outwash from the Iowithla advance is better preserved. The Nushagak and ancestral Mulchatna and Kvichak Rivers appear to have provided the drainage channels for these early Wisconsin advances. In the Taylor Mountains quadrangle to the north (Wilson, 2015), only a relatively minor abandoned channel that most likely carried meltwaters of the Mak Hill advance drains to the Nushagak River. This drainage channel was later diverted to the present Old Man Creek, which cuts across the terminal moraine of the Mak Hill advance and finally flows into the Mulchatna River. The lack of drainage pathways for the Mak Hill glacier and outwash is curious. A definitive explanation is not apparent; however, the Mak Hill glaciers may have stagnated in place and melted very slowly. On the west side of the map area, outwash from the Iowithla advance clearly flowed to the Nushagak River.

Even older glacial deposits in very subdued form are found farther down-glacier of these deposits and the landforms of the region show indistinct evidence of older glaciations. In the central part of the map area, evidence of old glaciations is reflected in scoured landforms, erratic boulders on isolated knobs, and deposits that appear to be outwash fans. The deep surficial deposits overlying the Kemuk mafic-ultramafic complex mentioned above are also evidence of older glacial advances.

The Kvichak moraine in the southeastern part of the Dillingham quadrangle has wellpreserved glacial landforms that largely control drainage patterns and locally show relatively abundant kettles and kettle lakes. The Kvichak advance of Detterman (1986) has an extensive outwash fan that may, in part, represent a long still-stand, and may also consist of outwash from younger late Wisconsin advances. The outwash fan outboard of the Kvichak terminal moraine extends at least 20 kilometers downstream from the terminal moraine (Stilwell and Kaufman, 1996). Stilwell and Kaufman (1996) report a radiocarbon age of $26,155 \pm 285{ }^{14} \mathrm{C}$ years B.P. (lab ID AA-15092) for plant macrofossils that underlie outwash they associated with the type Kvichak moraine. On the west side of the map area, absolute age determinations have not been reported. However, the Klak Creek glaciation of Briner and Kaufman $(2000,2008)$ in the western Ahklun Mountains, which is likely an equivalent of the Okstukuk advance, has a reported minimum radiocarbon age of 24,000 years.

\section{Glacial Lake Klutapuk}

Wilson (2015) described lake deposits that occur in the Klutapuk Creek valley and elsewhere in the Taylor Mountains quadrangle to the north. A large quantity of coarse outwash was deposited in glaciolacustrine fans that have since been largely eroded. These fans were deposited in a lake dammed by glaciers flowing from the Wood River Mountains to the west and 
the Alaska-Aleutian Range to the east that joined just to the north of the Dillingham quadrangle boundary and most likely extended well into the central Dillingham quadrangle. These glaciers dammed the Nushagak River and tributary drainages, developing a many-fingered glacial lake extending northward into the Taylor Mountains quadrangle (Wilson, 2006) and filling many other tributary valleys. Lea (1989) first suggested the presence of such a lake, dammed by advancing glaciers from the east and west. Although absolute age control is lacking, the evidence suggests that these glaciers were significantly older than the Wisconsin glaciations. Throughout the Taylor Mountains and northern Dillingham quadrangles, entrenched stream valleys containing present-day underfit streams provide ample evidence for significantly higher flow regimes in the past, which are interpreted here as indications of meltwater drainage from waning glaciers. Additionally, abandoned drainage channels cut through both glacial deposits and bedrock, providing further evidence of ample water flow. These features indicate a much larger glacial impact on the landscape than is generally assumed in this part of Alaska. Ultimately, Lake Klutapuk drained as the glaciers receded. In the southern part of the Dillingham quadrangle landforms are especially subdued, which may suggest that the drainage of this ancestral lake could have yielded a cataclysmic flood to the ocean. Travis Hudson (USGS, oral commun., 2006) described an inundation due to higher sea level along the Bering Sea coast, which may alternatively be responsible for these subdued landforms.

\section{DESCRIPTION OF MAP UNITS}

\section{UNCONSOLIDATED DEPOSITS}

us

tf

sf

es
Surficial deposits, undivided (Quaternary) - Poorly to well-sorted, poorly to moderately well-stratified deposits; consist of an undivided mixture of alluvial, colluvial, glacial, lacustrine, eolian, and swamp deposits. May contain permafrost locally; the Dillingham quadrangle is a transition zone between a northern area generally underlain by thick to thin permafrost and a southern area containing isolated masses, typically in fine-grained deposits (Ferrians, 1965). Unit locally subdivided into:

Modern tidal-flat deposits (Holocene) -Well-sorted, intertidal, stratified silt and some sand and local gravel deposited along tidally influenced sections of the Nushagak and Kvichak Rivers. Deposits reworked daily by tides in lower part, possibly only during highest tides or extreme storms in upper part. Largely mapped from the deposits as shown on topographic maps

Solifluction deposits (Holocene) - Solifluction mantle, interpreted from aerial photographs. Most likely consists of poorly sorted sand, silt, and clay derived in the northeastern part of the quadrangle from local upslope bedrock sources in western part of the adjacent Iliamna quadrangle. May include mixed-in organic matter

Estuarine deposits (Holocene)—Well-sorted, stratified silt and some sand deposited in shallow embayments. Likely represent uplifted tidal-flat deposits in part. Exposed in southern part of quadrangle along the Nushagak and Kvichak Rivers, and in large area in southwestern part of quadrangle south of Warehouse Mountain. The Snake and Weary 
$\mathrm{mt}$

Is

$\mathrm{cd}$

ed

b

Id

fg

al

Rivers flow through this large former embayment

Marine terrace deposits (Holocene? and Pleistocene) —-Inferred to be stratified, moderately well-sorted sand and gravel deposits that form nearly level plains that end locally at prominent wave-cut(?) scarps. Terraces occur at 5 to 10 meters elevation along the Nushagak and Wood Rivers; similar to estuarine deposits (unit es), these marine terrace deposits are at a higher topographic level

Landslide deposits (Holocene) — Coarse, subangular rock fragments to fine sand and silt having poorly to well-developed lobate morphology. These deposits are mostly recognized along the east side of the Nushagak River

Colluvial deposits (Holocene) - Chiefly rubble, gravel, sand, silt, and clay on uplands in the Muklung Hills, at Kemuk Mountain, and in northeastern part of the quadrangle. Includes talus and other slope debris deposits, may also include alluvium of minor streams, and locally, glacial and mass-wasting deposits. May include older glacial drift and locally grades into glacial deposits

Eolian deposits (Quaternary) —Well-sorted, irregularly(?) cross-bedded sand that forms active and stabilized dunes in southeastern part of quadrangle, exposed along western shore of the Kvichak River and likely blown from outwash plain in front of the Kvichak moraine

Beach deposits (Quaternary)—Moderately well-stratified and sorted sand and gravel on beaches of Nuyakuk and Tikchik Lakes. May locally include boulders and cobbles. The deposits in most lakes are too small to display at map scale

Lacustrine deposits (Quaternary) — Well-sorted, well-stratified clay, silt, and fine-sand deposited in former lake basins. Likely is covered by several feet of muck and peat. Found mostly on deposits of the oldest glacial advances. Aerial photograph interpretation

Fine-grained deposits (Quaternary) —Silt, sandy silt, and organic bog deposits (peat). These deposits, which tend to be locally swampy, may include areas of old outwash, lacustrine deposits, loess, and alluvial deposits including old terrace deposits. Largest area of development is northeast of the Muklung Hills and may reflect a former glacial lake dammed behind an Iowithla age moraine. In northeastern part of quadrangle, along floor of the Koktuli River and tributary valleys, deposits are most likely permafrost-rich and most likely reflect a largely abandoned drainage channel active during the waning stages of the late Wisconsin Kvichak and Iliamna glacial advances

\section{ALLUVIAL DEPOSITS}

Alluvial deposits — Subdivided into:

Flood-plain deposits (Holocene) — Mainly gravel and coarse-sand; consisting in part of glacial and glaciofluvial material reworked by postglacial streams. Ranges from coarse, subangular rock fragments to fine sand and silt 
af

td

tdo

ac

$\mathrm{nl}$

gc

gl

Alluvial fan and talus deposits (Holocene) — Gravel, silt, and sand, commonly occur at mouth of small side canyons. Range from coarse, angular rock fragments to fine sand and silt. Typically has welldeveloped cone forms or multiple cones coalescing into aprons

Terrace deposits (Quaternary) — Terrace gravel and sand originally deposited as older alluvium and outwash along stream and river channels. These deposits are likely of multiple ages across map area and may include small areas of older, higher level deposits

Older terrace deposits (Quaternary) —Older, higher level deposits along the Nushagak and Mulchatna Rivers

Abandoned channel deposits (Pleistocene) — Gravel, sand, and silt in abandoned or underfit stream channels, inferred in part to be relict glacial meltwater channels. Well-developed at limits of former glaciers. Includes a larger area east and south of the Muklung Hills that may represent drainage from a lobe of the Iowithla advance to the Nushagak River

Abandoned channel deposits, lake drainage (Pleistocene)Abandoned channel deposits that may reflect catastrophic draining of glacial Lake Klutapuk, which was located north of the Dillingham quadrangle (Wilson, 2015)

Inferred levee deposit (Pleistocene) - Inferred levee deposit along former meltwater drainage channel northeast of Kemuk Mountain. Most likely consists of sorted sand and gravel. The channel appears to have drained a lobe of the Iowithla advance. Alternatively, these deposits may reflect outwash deposited in a terrace

\section{GLACIAL DEPOSITS}

g Glacial deposits, undivided (Quaternary) - Undifferentiated glacial drift deposited during the last three or more(?) glacial advances. Consist of sand, gravel, and boulders. Include morainal and outwash deposits as well as undivided colluvium, talus, landslide debris, alluvium, and local silt. Found in scattered areas in the northern part of quadrangle. Where possible, subdivided into:

Glacial deposits in cirques (Holocene or late Wisconsin?) —-Small areas of undivided glacial deposits, including morainal and outwash deposits of neoglacial advance in small cirques exposed in the uplands around Lake Nerka and Lake Beverley and a small cirque on Kemuk Mountain that may be of late Wisconsin age

Glaciolacustrine deposits (late Pleistocene) -Well-sorted, well-stratified clay, silt, and fine sand deposited in ephemeral pre-glacial and postglacial lakes. May be covered by several feet of muck and peat and are transitional to swamp deposits (map unit fg). Deposits are exposed in two general areas. In the eastern part of the quadrangle, a lake was dammed behind the Kvichak moraine. This lake was an ancestral version of the present Iliamna Lake and drained when the moraine was breached by the Kvichak River. Downstream of the breach, a broad 
floodplain contains outwash deposits derived from the Kvichak advance, and likely includes outwash or flood deposits that may reflect the Iliamna advance. The second major area of glaciolacustrine deposits are found in the vicinity of Lakes Tikchik, Beverley, Nerka, and Aleknagik in the western part of the quadrangle. These western deposits reflect more areally extensive phases of the lakes, which are contained behind moraines of the Aleknagik advance, and hence, likely represent deposits of younger lakes than the deposits of the eastern part of the quadrangle behind the Kvichak moraine. Additional small areas of lacustrine deposits are found outboard of the Okstukuk moraines. The deposits outboard of the Okstukuk moraine west of Kemuk Mountain and within the Muklung Hills are dammed behind glacial deposits of interpreted Iowithla age and hence may reflect much older lakes. Scattered in the south-central part of the quadrangle are many small areas of lake deposits that most likely reflect the draining of kettles in older moraines and hence are most likely the oldest of the lacustrine deposits

ak

aky

ako

ok

Drift, Aleknagik glaciation (late Pleistocene)—Glacial deposits including end, lateral, recessional, and ground moraine and outwash. Lea (1989) correlates with Iliamna advance of the Brooks Lake glaciation, suggesting a late Wisconsin age. Most likely includes deposits equivalent to the younger Newhalen and possibly Iliuk advances of the Brooks Lake glaciation. Locally subdivided into:

Youngest advance, Aleknagik glaciation-End moraine exposed in two areas. End moraine forms the southeast limit of Nunavaugaluk Lake as well as a morainal ridge to the south in the floodplain of the Weary River. These deposits are among the few that clearly indicate the Aleknagik glaciation had multiple advances. Remnants of older Aleknagik advances appear outboard of these deposits and, because they are surrounded by estuarine deposits, may reflect a tidewater terminating glacier at this locality. A second area of exposure is on Kemuk Mountain where the deposits of a number of alpine glaciers remain on the north side of the mountain; Platt and Muller (USGS, unpub. data, 1957) assigned these deposits to the Okstukuk advance. However, the freshness of their appearance suggests they are younger

Outwash, Aleknagik glaciation-Stratified gravel and sand of outwash aprons, finer grained, better sorted, and thinner at a distance from associated moraines of the Aleknagik glaciation than near them (J.N. Platt and E.H. Muller, USGS, unpub. data, 1957). Found inboard of drift of the Okstukuk glaciation

Drift, Okstukuk glaciation (late Pleistocene)—Glacial deposits including end, lateral, and minor ground moraine. Platt and Muller originally correlated this unit with the Mak Hill advance, whereas Lea (1989) correlated it with the Kvichak advance of the Brooks Lake glaciation, which I accept here, suggesting a late Wisconsin age and therefore making this advance equivalent to the late Wisconsin glacial maximum 
bk

IW

Iwo

ig

Drift, Brooks Lake glaciation, Kvichak advance (late Pleistocene)-

Consists of end and lateral moraine of the oldest and most extensive of the four advances of the Brooks Lake glaciation (Detterman, 1986). The Dillingham quadrangle is the type area for the deposits of this advance, which tends to have well-developed and areally extensive associated outwash deposits. Generally accepted to be of late Wisconsin age and representing the glacial maximum. A radiocarbon age from outwash along the Kvichak River, $20 \mathrm{~km}$ downstream of the type Kvichak moraine, was interpreted by Stilwell and Kaufman (1996) to date this advance at $26,155 \pm 285{ }^{14} \mathrm{C}$ years B.P. This date is analytically identical to a date of $26,570 \pm 320{ }^{14} \mathrm{C}$ years B.P. reported by Mann and Peteet (1994) from the equivalent Naknek moraine on the northern Alaska Peninsula, which is thought to define the timing of the late Wisconsin glacial maximum in this region. However, the distance of the sample site from the morainal deposits makes the Stilwell and Kaufman (1996) date less than conclusive. It may date outwash from a later advance and is in any case a minimum age

Ground moraine (late Pleistocene)—Ground moraine of the Okstukuk and Kvichak advances of late Wisconsin age. These advances reflect the late Wisconsin glacial maximum. Consist of unsorted till; may also include minor outwash, alluvial and eolian deposits

Outwash (late Pleistocene)—Consists of stratified gravel and sand in outwash aprons of the Okstukuk glaciation and the Kvichak advance of the Brooks Lake glaciation. Most extensive deposits are associated with the Kvichak advance in the southeastern part of the quadrangle; these may also include outwash from advances younger than the Kvichak advance. Associated with these deposits is an area that has unusual character and is thought to reflect a sand sheet or sandur resulting from a glacial outburst flood. These deposits are exposed on both sides of the Nushagak River and are prominent north of the confluence of the Nushagak and Mulchatna Rivers. They form a linear array trending northwest across old glacial deposits and also appear to originate from outwash of the Kvichak advance. In the southwestern part of the quadrangle, the glaciers of the Okstukuk glaciation may have terminated in tidewater; no outwash deposits have been mapped associated with that particular lobe

Drift, Iowithla glaciation (Pleistocene)-Undivided glacial deposits, primarily end and lateral moraines, composed chiefly of unsorted coarse gravel and coarse gravelly till, with silty clay matrix, as described by J.N. Platt and E.H. Muller (USGS, unpub. data, 1957). Extensively mantled by several feet of silt, muck, and peat, except on knolls and ridges. Older than late Wisconsin age and possibly equivalent to the Mak Hill glaciation (unit mh) in age, hence early Wisconsin. In the Taylor Mountains quadrangle to the north (Wilson, 2015) there is some evidence that this event may have had multiple advances; similar evidence has been noted for the Mak Hill glaciation 


\section{igg}

io

igd

$\mathrm{mh}$

mhg

mho

mhd

ek

ud on the Alaska Peninsula (Detterman and others, 1981; Riehle and Detterman, 1993). Locally subdivided into:

Ground moraine, Iowithla glaciation—Ground moraine of unsorted till, as described above, may include some organic and lacustrine material

Outwash, Iowithla glaciation —Stratified gravel and sand of outwash aprons and plains of the Iowithla glaciation

Drumlins, Iowithla glaciation-Drumlins in outwash plains of the Iowithla glaciation in northern part of quadrangle, east of Tikchik Lake

Drift, Mak Hill glaciation (Pleistocene) — Undivided glacial deposits including end, lateral, recessional, and ground moraine, and local outwash deposits considered equivalent to the deposits of the Mak Hill glaciation of Detterman (1986). Generally considered early Wisconsin in age by Detterman (1986). Primarily identified and mapped in the northeastern part of quadrangle. In more southern part of the quadrangle, it can be difficult to distinguish from the older glacial deposits and it is therefore discontinuously depicted. Locally subdivided into:

Ground moraine, Mak Hill glaciation-Ground moraine of unsorted till, as described above, includes some organic and lacustrine material. Best displayed in the southeastern part of the quadrangle; it appears to be more easily distinguished than the limit of the end moraine

Outwash, Mak Hill glaciation-Stratified gravel and sand of outwash aprons and plains of the Mak Hill glaciation. Deposits assigned to this unit are largely limited to the northeastern part of the quadrangle. Wilson (2015) noted that this map unit has limited extent, especially considering the large size of the Mak Hill moraine in the Taylor Mountains quadrangle to the north. In the southeastern part of the quadrangle, the exposures of this outwash are restricted in area; presumably most outwash material was transported southward to the Naknek quadrangle or to Bristol Bay

Drumlins, Mak Hill glaciation-Drumlins in outwash plains of the Mak Hill glaciation

Esker deposits (Pleistocene) - Small area in northeastern part of quadrangle, north of the Mulchatna River at approximately $156^{\circ} 45^{\prime} \mathrm{W}$. longitude. Deposits occur in two ridges in ground moraine displaying kettles inferred to be of Mak Hill age, though may be older

Drift, unnamed glaciations (early Pleistocene)—Undivided drift, most likely reflecting end, ground, and recessional moraine deposits, as well as other glacial and glaciofluvial materials. Extensively mantled by colluvium, silt, muck, and peat. Moraine topography, where recognizable, is much subdued and modified (J.N. Platt and E.H. Muller, USGS, unpub. data, 1957). These deposits were derived from both western and eastern parts of map area. These deposits may be 
equivalent in age to the Halfmoon Bay and Nichols Hill advances exposed in bluff sections along the coast of the Nushagak Peninsula and northern Bristol Bay (Lea, 1989) or the deposits of the Johnson Hill glaciation and "oldest" drift of Detterman (1986). Locally subdivided into:

Ground moraine, unnamed glaciations-Ground moraine, most likely includes some organic and lacustrine material. These deposits have the appearance of ground moraine; however, the visual distinction between these deposits and that of unit ud is subtle and may be subject to reinterpretation by others

uo Outwash, unnamed glaciations - Stratified gravel and sand of outwash aprons, also most likely includes some organic and lacustrine material. These deposits are primarily found on the west side of the Nushagak River at its confluence with the Mulchatna River. They may include some outwash of early Wisconsin age of the Iowithla or Mak Hill glaciations

\section{BEDROCK}

sb Scoured bedrock - Small areas of glacially scoured bedrock covered by a thin(?) mantle of unconsolidated surficial deposits. Age of scouring is most likely Quaternary; age of underlying bedrock is early Tertiary or older and likely to be plutonic

Bedrock, undivided-Bedrock of Tertiary and older age including latest Cretaceous to earliest Tertiary plutons, Tertiary volcanic rocks, and older sedimentary and igneous rocks. Not labeled on map 


\section{References Cited}

Abrahamson, S.R., 1949, Geography of the Naknek region, Alaska: Worcester, Mass., Clark University, Ph.D. dissertation, 148 p.

Beikman, H.M., 1980, Geology of Alaska: U.S. Geological Survey, 1 sheet, scale 1:2,500,000.

Berg, H.C., and Cobb, E.H., 1967, Metalliferous lode deposits of Alaska: U.S. Geological Survey Bulletin 1246, 254 p.

Briner, J.P., and Kaufman, D.S., 2000, Late Pleistocene glaciation of the southwestern Ahklun Mountains, Alaska: Quaternary Research, v. 53, p. 13-22.

Briner, J.P., and Kaufman, D.S., 2008, Late Pleistocene mountain glaciation in Alaska-Key chronologies: Journal of Quaternary Science, v. 23, p. 659-670.

Coulter, H.W., Péwé, T.L., Hopkins, D.M., Wahrhaftig, Clyde, Karlstrom, T.N.V., and Williams, J.R., 1965, Map showing extent of glaciations in Alaska; Compiled by the Alaska Glacial Map Committee of the U.S. Geological Survey: U.S. Geological Survey Miscellaneous Geologic Investigations Map I-415, scale 1:2,500,000.

Detterman, R.L., 1986, Glaciation of the Alaska Peninsula, in Hamilton, T.D., Reed, K.M., and Thorson, R.M., eds., Glaciation in Alaska, the geologic record: Alaska Geological Society, p. 151-170.

Detterman, R.L., Miller, T.P, Yount, M.E., and Wilson, F.H., 1981, Quaternary geologic map of the Chignik and Sutwik Island quadrangles, Alaska: U.S. Geological Survey Miscellaneous Investigations Series Map I-1292, 1 sheet, scale 1:250,000.

Ferrians, O.J., Jr., 1965, Permafrost map of Alaska: U.S. Geological Survey Miscellaneous Geologic Investigations Map I-445, 1 sheet, scale 1:2,500,000.

Hoare, J.M., and Coonrad, W.L, 1978, Geologic map of the Goodnews and Hagemeister Island quadrangles region, southwestern Alaska: U.S. Geological Survey Open-File Report 78-9-B, 2 sheets, scale 1:250,000.

Jorgenson, Torre, Yoshikawa, Kenji, Kanevskiy, Mikhail, Shur, Yuri, Romanovsky, Vladimir, Marchenko, Sergei, Grosse, Guido, Brown, Jerry, and Jones, Ben, 2008, Permafrost characteristics of Alaska: Institute of Northern Engineering, University of Alaska Fairbanks, 1 sheet, scale 1:7,200,000.

Karlstrom, T.N.V., compiler, 1964, Surficial geology of Alaska: U.S. Geological Survey Miscellaneous Investigations Series Map I-357, 2 sheets, scale 1:1,584,000.

Lea, P.D., 1989, Quaternary environments and depositional systems of the Nushagak Lowland, southwestern Alaska: Boulder, University of Colorado, Ph.D. dissertation, 355 p., 72 figs., 5 tables.

Manley, W.F., Kaufman, D.S., and Briner, J.P., 2001, Pleistocene glacial history of the southern Ahklun Mountains, southwestern Alaska-Soil-development, morphometric, and radiocarbon constraints: Quaternary Science Reviews, v. 20, p. 353-370.

Mann, D.H., and Peteet, D.M., 1994, Extent and timing of the last glacial maximum in southwestern Alaska: Quaternary Research, v. 42, p. 136-148.

Mertie, J.B., Jr., 1938, The Nushagak District, Alaska: U.S. Geological Survey Bulletin 903, 96 p., 2 plates in pocket.

Mohadjer, Solmaz, Wilson, F.H., and Saltus, R.W., 2006, Geologic and geophysical views of the Mulchatna lineament of southwest Alaska [abs.]: Geological Society of America Abstracts with Programs, v. 38, no. 5, p. 17. 
Muller, E.H., 1953, Northern Alaska Peninsula and eastern Kilbuck Mountains, Alaska, in Péwé, T.L., and others, eds., Multiple glaciations in Alaska: U.S. Geological Survey Circular 289, p. 2-3.

Péwé, T.L., 1975, Quaternary geology of Alaska: U.S. Geological Survey Professional Paper 835, 145 p., 3 plates.

Riehle, J.R., and Detterman, R.L., 1993, Quaternary geologic map of the Mount Katmai quadrangle and adjacent parts of the Naknek and Afognak quadrangles, Alaska: U.S. Geological Survey Miscellaneous Investigations Series Map I-2032, 1 sheet, scale 1:250,000.

Saltus, R.W., and Simmons, G.C., 1997, Composite and merged aeromagnetic data for AlaskaA web site for distribution of gridded data and plot files: U.S. Geological Survey Open-File Report 97-520., 15 p., accessed Oct. 2016 at http://pubs.usgs.gov/of/1997/ofr-970520/alaskamag.html.

Stilwell, K.B., and Kaufman, D.S., 1996, Late Wisconsin glacial history of the Northern Alaska

Peninsula, Southwestern Alaska, U.S.A.: Arctic and Alpine Research, v. 28, no. 4, p. 475-487.

Wahrhaftig, Clyde, 1965, Physiographic divisions of Alaska: U.S. Geological Survey Professional Paper 482, 52 p., 6 plates.

Wilson, F.H., 2006, Ephemeral glacial lakes in southwestern Alaska [abs.]: Geological Society of America Abstracts with Programs, v. 38, no. 5, p. 30.

Wilson, F.H., 2015, Reconnaissance surficial geologic map of the Taylor Mountains quadrangle, southwestern Alaska: U.S. Geological Survey Scientific Investigations Map 3334, 12 p., 1 sheet, scale 1:250,000, https://doi.org/10.3133/sim3334.

Wilson, F.H., Blodgett, R.B., Blome, C.D., Mohadjer, Solmaz, Preller, C.C., Klimasauskas, E.P., Gamble, B.M., and Coonrad, W.L., 2017, Bedrock geologic map of the northern Alaska Peninsula area, southwestern Alaska: U.S. Geological Survey Scientific Investigations Map 2942, pamphlet 43 p., scale 1:350,000, https://doi.org/10.3133/sim2942.

Wilson, F.H., Hudson, T.L., Grybeck, Donald, Stoeser, D.B., Preller, C.C., Bickerstaff, Damon, Labay, Keith, and Miller, M.L., 2003, Preliminary geologic map of the northeast Dillingham quadrangle (D-1, D-2, C-1, and C-2), Alaska: U.S. Geological Survey Open-File Report 03105, 13 p., scale 1:100,000, http://pubs.usgs.gov/of/2003/0105/.

Wilson, F.H., Mohadjer, Solmaz, Labay, K.A., and Shew, Nora, 2006, Digital datasets for geologic map, by Wilson, F.H., Blodgett, R.B., Blome, C.D., Mohadjer, Solmaz, Preller, C.C., Klimasauskas, E.P., Gamble, B.M., and Coonrad, W.L., Preliminary integrated geologic map databases for the United States: Digital data for the reconnaissance bedrock geologic map for the northern Alaska Peninsula area, southwest Alaska: U.S. Geological Survey Open-File Report 2006-1303, accessed Oct 2016 at http://pubs.usgs.gov/of/2006/1303/. 